\title{
Tree stand floristic dynamics in secondary forests of different ages in Sarawak, Malaysia
}

\author{
KARYATI ${ }^{1, \boldsymbol{}}$, ISA B. IPOR ${ }^{2}$, ISMAIL JUSOH ${ }^{2}$, MOHD. EFFENDI WASLI ${ }^{2}$ \\ ${ }^{1}$ Faculty of Forestry, Universitas Mulawarman. Jl. Ki Hajar Dewantara, Gunung Kelua, Samarinda 75123, East Kalimantan, Indonesia. \\ Tel.: +62 541 35089, Fax.: +62 541 732146, "email: karyati@fahutan.unmul.ac.id \\ ${ }^{2}$ Faculty of Resource Science and Technology, Universiti Malaysia Sarawak. 94300 Kota Samarahan, Sarawak, Malaysia
}

Manuscript received: 1 July 2017. Revision accepted: 1 April 2018.

\begin{abstract}
Karyati, Ipor IB, Jusoh I, Wasli ME. 2018. Tree stand floristic dynamics in secondary forests of different ages in Sarawak, Malaysia. Biodiversitas 19: 767-773. Succession is a series sequential processes of the development of floristic community which involves changes in community structure, species composition and diversity over time. The information on tree stand floristic dynamics of various stages of succession in secondary forests in Malaysia is currently lacking. This study was conducted to determine tree stand structure, floristic composition, and species diversity in various stages of secondary forest development in the study areas. A total of 997, 1,842, and 834 tree stems with diameter at breast height (DBH) of $\geq 5 \mathrm{~cm}$ were recorded in one-hectare-plots of 5, 10, and 20 year old secondary forests, respectively. The ten most common species in 5 and 10 year old of secondary forests consisted mostly of light demanding species. In the 20 year old secondary forest, these species did not exist. Macaranga gigantea was the most dominant tree species in the 5 and 10 year old secondary forests in terms of basal area and volume per hectare. The most common species, based on density, basal area, volume, and Importance Value Index (IVi), in the 20 year old secondary forest was Adinandra dumosa. The diversity and richness indices of the 10 year old secondary forest were the highest among all study sites.
\end{abstract}

Keywords: Floristic composition, diversity, secondary forest, vegetation structure, succession

Abbreviations: DBH: Diameter at Breast Height; BA: Basal Area; V: volume; $H^{\prime}$ : Shannon-Wiener's diversity index; $D_{s}$ : Simpson's dominance index; $J^{\prime}$ : Pielou's evenness index; $R$ : Margalef's richness index; ISS: Sørensen similarity index

\section{INTRODUCTION}

The primary forests of Sarawak are shrinking due to the combination of logging and shifting cultivation. They are replaced by secondary forests with lower stature and altered species composition (Primack and Hall 1992; Jomo et al. 2004). Human disturbances bring negative effects to forest and cause lower species diversity and simplified community structure (Dianpei et al. 2004). Following field abandonment, secondary forest develops naturally (Van Do et al. 2010). Secondary forests are identified by their structure and extent of vegetative cover, as well as their composition in terms of dominant and secondary species (Mittelman 2001; Van Breugel et al. 2006). Without additional disturbances, secondary forests will undergo succession and develop into forests with structure similar to that of the original forests (Kartawinata et al. 2001). The dynamics at several temporal periods of forest disturbances determine plant diversity within a regenerating fallow (Lawrence 2004). Brearley et al. (2004) stated that fiftyfive years of succession is insufficient for the recovery of the most primary forest species. The secondary forests are especially vital in conserving biodiversity because they provide the last remaining corridors (Mittelman 2001). Karyati et al. (2013) reported that plant seedlings and saplings in 3 and 5 year old secondary forests in Sabal area of Sarawak were dominated by light demanding and fast growing species, such as Melastoma malabathricum L.,
Ploiarium alternifolium Melchior, and Ficus aurata Miq. as well as Dillenia spp. and Macaranga spp. Dillenia suffruticosa Martelli was also a common species in both 10 and 20 year old secondary forests.

Information on the capability of abandoned land after forest disturbance in providing ecological functions is vital in order to ease the pressure on the natural forest ecosystem as an ecotone for balancing the tropical forest ecosystem. Many studies had been done on the floristic composition and stand structure of the tropical forest in Borneo Island, but few similar studies have been done in various stages of secondary forests in Sarawak.

This study was conducted in order to determine the community structure, floristic composition, and species diversity of tree stand in secondary forests of different ages during early secondary succession process at abandoned lands.

\section{MATERIALS AND METHODS}

\section{Study sites}

The study was carried out in three stages of fallows (period of abandonment), namely 5 year old, 10 year old, and 20 year old secondary forests in Sabal, Sri Aman, Sarawak, East Malaysia (Figure 1). The geographic locations of these sites are $01^{\circ} 04^{\prime} 43.3^{\prime \prime} \mathrm{N} 110^{\circ} 59^{\prime} 02.0^{\prime \prime} \mathrm{E}$, $01^{\circ} 03^{\prime} 55.9^{\prime \prime} \mathrm{N} \quad 110^{\circ} 55^{\prime} 51.4^{\prime \prime} \mathrm{E}, \quad$ and $01^{\circ} 03^{\prime} 59.3^{\prime \prime} \mathrm{N}$ 
$110^{\circ} 53^{\prime} 34.4^{\prime \prime} \mathrm{E}$, respectively. The same sites had been studied previously for composition and diversity of seedlings and saplings (Karyati et al. 2013) as well as their soil properties (Karyati et al. 2014). The study plots at Sabal were located approximately $110 \mathrm{~km}$ southeast of Kuching along the Kuching-Sri Aman Road and 5 to $15 \mathrm{~km}$ from the Sabal Agroforestry Centre. The study sites had similar histories of abandonment after shifting cultivation, as told by the land owner and confirmed by Sabal Agroforestry Centre staff. The original vegetation at Sabal site was lowland mixed dipterocarp forest with heath forest (kerangas) (Kendawang et al. 2007). In the study sites, the soil was categorized as acidic soil, indicated by the $\mathrm{pH}$
$\left(\mathrm{H}_{2} \mathrm{O}\right)$ values of lower than 5 and the low content of T-C, T-N and exchangeable bases (Karyati et al. 2014).

\section{Data collection}

The surveys of vegetation were conducted in 5,10 , and 20 year old secondary forests. Twenty five sub plots each measuring $20 \mathrm{~m} \times 20 \mathrm{~m}$ were established within each study site. The diameter at breast height $(\mathrm{DBH})$ and total height of all woody trees with $\mathrm{DBH}$ of $\geq 5 \mathrm{~cm}$ within the plots were enumerated and their species were identified. Nomenclature was checked in the flora records of the study area (Anderson 1980; Jawa and Chai 2007).

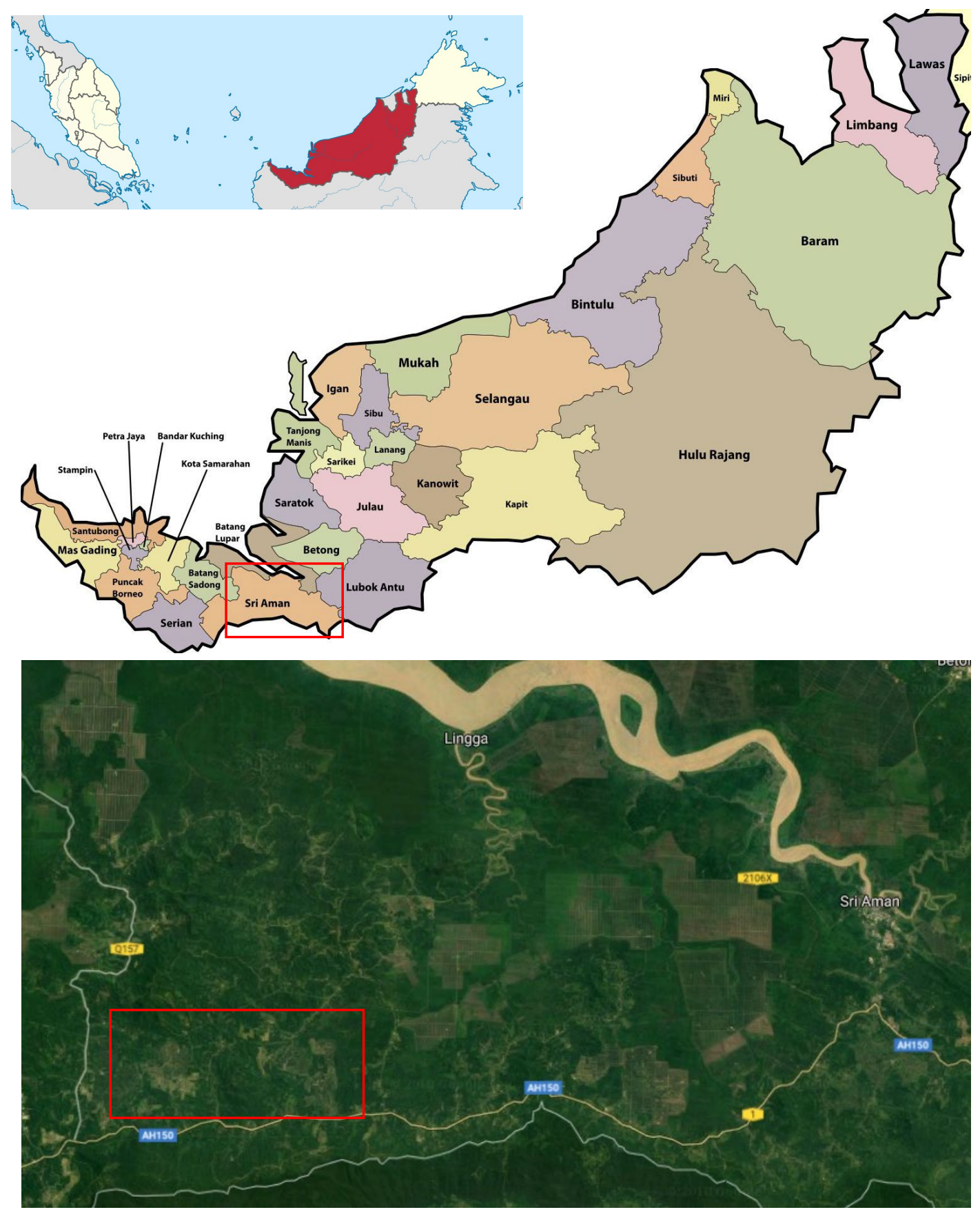

Figure 1. Map of the study area in Sabal, Sri Aman, Sarawak, East Malaysia 


\section{Data analysis}

The dominant species of forest community were determined by importance value index (IVi) of species within the plots (Fachrul 2007). The similarity of species composition among different communities was determined using Sørensen similarity index (ISS) (Fachrul 2007). The diversity indices of Shannon-Wiener's diversity index $\left(H^{\prime}\right)$, Simpson's dominance index $\left(D_{s}\right)$, Pielou's evenness index $\left(J^{\prime}\right)$, and Margalef's richness index $(R)$ were used to measure species diversity of standing trees in each community (Odum 2005). The mean values of $H^{\prime}, D s, J^{\prime}$, and $R$ for each site were compared with one-way analysis of variance (ANOVA) by Tukey's tests. All statistical tests were conducted using SPSS version 18 for Windows (SPSS Inc. 2012).

\section{RESULTS AND DISCUSSION}

\section{Stand structure}

Diameter at Breast Height (DBH) and Height Distributions

The density of trees among $\mathrm{DBH}$ classes differed among three succession stages of secondary forests. The total number of trees decreased as the $\mathrm{DBH}$ increased, and generally forms L-shaped distribution as shown in Figure 2. The tree DBH distribution in secondary forests in the study sites were skewed towards the smaller DBH classes, with more than $90 \%$ of all trees with the DBH of $\geq 5 \mathrm{~cm}$ in the $5.0-10.0 \mathrm{~cm}$ class for the 5 and 10 year old secondary forests, while in the 20 year old secondary forest all trees with the DBH of $\geq 5 \mathrm{~cm}$ in the $5.0-10.0 \mathrm{~cm}$ class constituted more than $45 \%$ of the total number of tree species. The reverse-J-shaped tree diameter distributions were reported for secondary forests (Álvarez-Yépiz et al. 2008; Feldpausch et al. 2007). The distribution of height classes at different interval classes was slightly positively skewed at each of the three study sites (Figure 3).

\section{Density, basal area, and volume}

The highest density was recorded in the 10 year old secondary forest (1,842 stem per hectare) as presented in Table 1. Three species such as Macaranga gigantea Mull. Arg., Vitex pubescens Vahl., and Dillenia suffruticosa Martelli were dominant in terms of density, basal area and volume per hectare in the 5 and 10 year old secondary forests. Several pioneer species, such as Macaranga hypoleuca Mull. Arg. and Macaranga caladifolia Becc. were also common in the 10 year old secondary forest, and Macaranga trichocarpa Mull. Arg. in the 5 year old secondary forest. In the 20 year old secondary forest, Adinandra dumosa Jack, Artocarpus integer (Thunb.) Merr., Cratoxylum arborescens Blume. and Pellacalyx axillaris Korth. were the dominant species based on the number of stems, basal area, and volume per hectare.

The total basal area and volume per hectare increased with the increasing period of abandonment. The increase of $\mathrm{DBH}$ and height caused increase in total basal area and volume per hectare in the study sites. This indicated that during successional process many seedlings and saplings had grown into larger trees in the older secondary forest. The dynamics and development of secondary forests were showed by the trends in increasing average DBH, height, basal area and volume following the increasing fallow age.

\section{Floristic composition \\ Importance Value Index (IVi)}

The ten most common species consisted mostly of light demanding pioneer and fast growing species in the 5 and 10 year old secondary forests, such as Macaranga spp., $D$. suffruticosa, and $V$. pubescens in terms of IVi (Table 2). The dominance of pioneer species appeared in early successional stage, and decreased gradually in the 20 year old secondary forest. The late pioneer species and secondary species were dominant in the 10 and 20 year old secondary forests. The secondary rain forest consists of long-lived intolerant trees, big pioneers, and fast-growing species. This study showed that under similar land use change (due to slash and burn), the species composition of trees with $\mathrm{DBH}$ of $\geq 5 \mathrm{~cm}$ changed gradually during early secondary succession process at abandoned lands after shifting cultivation. The development of vegetation after slash and burn process at different ages of fallow lands can be observed, in terms of density, total basal area, and volume per hectare. It is mainly influenced by secondary succession process and fallow age at abandoned lands. As the average $\mathrm{DBH}$ and height as well as basal area and volume increased with increasing fallow ages, the results showed that the secondary forests would continue to develop into mature forest. The results also showed that there were similar species composition in the 5 and 10 year old secondary forests. However, the 20 year old secondary forest showed relatively different species composition among three study sites. This showed that species composition at abandoned lands after burning began to change after 20 years of abandonment. Van Breugel et al. (2006) stated that forest development can show gradual or abrupt changes, depending on the species composition and the degree of dominance by one or few species. Species composition may explain differences in forest structure; particularly stem density and basal area or biomass, across sites (Marin-Spiotta et al. 2007).

\section{Similarity index}

The Sørensen similarity index between the 5 and the 20 year secondary forests was the highest $(52.17 \%)$, followed by the 10 and the 20 year old secondary forests $(44.12 \%)$, and the 5 and the 10 year old secondary forests $(41.70 \%)$ (Table 3). The similarities of trees (DBH of $\geq 5 \mathrm{~cm}$ ) were intermediate among all study sites. The results showed that the early stage of secondary succession of fallow lands after shifting cultivation had many common species. This indicated that the compositions of species were dominated by similar species during successional process at different stages of fallow periods. 
Table 1. Density, basal area, and volume of ten most common species (DBH of $>5 \mathrm{~cm}$ ) in 1 hectare of each study site

\begin{tabular}{|c|c|c|c|c|c|c|c|c|c|}
\hline \multirow{2}{*}{ Species } & \multicolumn{3}{|c|}{ SF-5 years old } & \multicolumn{3}{|c|}{ SF-10 years old } & \multicolumn{3}{|c|}{ SF-20 years old } \\
\hline & $\mathbf{N}$ & BA & $\mathbf{V}$ & $\mathbf{N}$ & BA & $\mathbf{V}$ & $\mathbf{N}$ & BA & $\mathbf{V}$ \\
\hline Adinandra dumosa Jack & & & & & & & 169 & 3.62 & $32.50(1)$ \\
\hline Alphitonia excelsa Reissek ex Endl. & 53 & 0.20 & $0.82(7)$ & & & & & & \\
\hline Alstonia spatulata Blume & & & & 15 & 0.15 & $1.57(7)$ & & & \\
\hline Artocarpus integer (Thunb.) Merr. & & & & & & & 35 & 0.94 & $11.13(2)$ \\
\hline Cratoxylum arborescens Blume. & 19 & 0.08 & $0.37(10)$ & & & & 11 & 0.79 & $9.63(3)$ \\
\hline Cratoxylum formosum Benth. \& Hook. f. ex Dyer & & & & & & & 6 & 0.22 & $3.33(7)$ \\
\hline Cratoxylum glaucum Korth. & 72 & 0.30 & $1.40(5)$ & & & & & & \\
\hline Dillenia suffruticosa Martelli & 115 & 0.33 & $1.23(6)$ & 224 & 0.68 & $2.34(5)$ & & & \\
\hline Endospermum diadenum (Miq.) Airy Shaw & & & & 39 & 0.23 & $1.47(9)$ & 20 & 0.39 & $3.23(9)$ \\
\hline Euodia glabra (B1.) Bl. & 85 & 0.36 & $1.56(3)$ & & & & 14 & 0.35 & $4.25(5)$ \\
\hline Glochidion arborescens Blume. & 25 & 0.12 & $0.55(8)$ & & & & & & \\
\hline Macaranga caladifolia Becc. & & & & 66 & 0.33 & $1.79(6)$ & & & \\
\hline Macaranga gigantea Mull. Arg. & 112 & 0.60 & $2.83(1)$ & 81 & 0.90 & $6.50(1)$ & & & \\
\hline Macaranga hypoleuca Mull. Arg. & & & & 42 & 0.32 & $2.51(4)$ & & & \\
\hline Macaranga pruinosa Mull. Arg. & & & & 32 & 0.20 & $1.27(10)$ & & & \\
\hline Macaranga trichocarpa Mull. Arg. & 88 & 0.35 & $1.48(4)$ & & & & & & \\
\hline Macaranga triloba Mull. Arg. & & & & 83 & 0.52 & $3.41(2)$ & & & \\
\hline Nephelium cuspidatum Blume & & & & 60 & 0.26 & $1.48(8)$ & & & \\
\hline Palaquium decurrens H.J. Lam & & & & & & & 14 & 0.27 & $3.32(8)$ \\
\hline Pellacalyx axillaris Korth. & & & & & & & 53 & 0.91 & $8.09(4)$ \\
\hline Saurauia glabra (Ruiz \& Pav.) Soejarto & & & & & & & 22 & 0.35 & $3.12(10)$ \\
\hline Timonius flavescens Baker & & & & & & & 32 & 0.43 & $3.64(6)$ \\
\hline Vernonia arborea Buch. Ham. & 19 & 0.10 & $0.47(9)$ & & & & & & \\
\hline Vitex pubescens Vahl. & 120 & 0.43 & $1.83(2)$ & 135 & 0.67 & $3.35(3)$ & & & \\
\hline Total & 708 & 2.87 & 12.55 & 777 & 4.25 & 25.72 & 376 & 8.26 & 82.24 \\
\hline Total per hectare & 997 & 3.87 & 16.73 & 1,842 & 9.11 & 53.12 & 834 & 14.06 & 133.73 \\
\hline
\end{tabular}

Note: $\mathrm{SF}=$ secondary forest, $\mathrm{N}=$ density $\left(\right.$ stem ha $\left.\mathrm{h}^{-1}\right), \mathrm{BA}=$ basal area $\left(\mathrm{m}^{2} \mathrm{ha}^{-1}\right)$, and $\mathrm{V}=$ volume $\left(\mathrm{m}^{3} \mathrm{ha}^{-1}\right)$. The figures in parentheses are the ranking in terms of volume, (1) being the species with the highest volume

Table 2. Importance value index (IVi) of ten most common species of trees (DBH of $>5 \mathrm{~cm}$ ) in 1 hectare of each study site

\begin{tabular}{|c|c|c|c|c|}
\hline Species & Family & $\begin{array}{c}\text { SF-5 } \\
\text { years old } \\
\end{array}$ & $\begin{array}{c}\text { SF-10 } \\
\text { years old }\end{array}$ & $\begin{array}{c}\text { SF-20 } \\
\text { years old }\end{array}$ \\
\hline Adinandra dumosa Jack & Theaceae & & $7.81(8)$ & $50.34(1)$ \\
\hline Alphitonia excelsa Reissek ex Endl. & Rhamnaceae & $15.61(7)$ & & \\
\hline Artocarpus integer (Thunb.) Merr. & Moraceae & & & $14.70(3)$ \\
\hline Cratoxylum arborescens Blume. & Clusiaceae & & & $9.26(5)$ \\
\hline Cratoxylum glaucum Korth. & Clusiaceae & $17.72(6)$ & & \\
\hline Dillenia suffruticosa Martelli & Dilleniaceae & $26.43(3)$ & $21.74(1)$ & \\
\hline Endospermum diadenum (Miq.) Airy Shaw & Euphorbiaceae & & $7.26(9)$ & $7.97(7)$ \\
\hline Euodia glabra (B1.) Bl. & Rutaceae & $24.19(5)$ & & $5.94(10)$ \\
\hline Ficus aurata Miq. & Moraceae & $8.99(9)$ & & \\
\hline Glochidion arborescens Blume. & Euphorbiaceae & $9.58(8)$ & & \\
\hline Macaranga caladifolia Becc. & Euphorbiaceae & & $9.32(5)$ & \\
\hline Macaranga gigantea Mull. Arg. & Euphorbiaceae & $31.16(1)$ & $17.41(2)$ & \\
\hline Macaranga hypoleuca Mull. Arg. & Euphorbiaceae & & $8.56(6)$ & \\
\hline Macaranga trichocarpa Mull. Arg. & Euphorbiaceae & $24.26(4)$ & & \\
\hline Macaranga triloba Mull. Arg. & Euphorbiaceae & & $13.39(4)$ & \\
\hline Nephelium cuspidatum Blume & Sapindaceae & & $8.43(7)$ & $7.26(8)$ \\
\hline Pellacalyx axillaris Korth. & Rhizophoraceae & & & $16.19(2)$ \\
\hline Saurauia glabra (Ruiz \& Pav.) Soejarto & Actinidiaceae & & & $8.19(6)$ \\
\hline Timonius flavescens Baker & Rubiaceae & & & $9.97(4)$ \\
\hline Vernonia arborea Buch. Ham. & Asteraceae & $7.45(10)$ & & \\
\hline Vitex pubescens Vahl. & Verbenaceae & $30.34(2)$ & $16.48(3)$ & $6.57(9)$ \\
\hline Whiteodendron moultonianum (W.W.Sm.) Steenis & Myrtaceae & & $6.93(10)$ & \\
\hline Number of families & & 28 & 45 & 43 \\
\hline Number of genera & & 43 & 107 & 75 \\
\hline Number of species & & 62 & 173 & 99 \\
\hline
\end{tabular}

Note: $\mathrm{SF}=$ secondary forest. The figures in parentheses are the ranking in terms of IVi, (1) being the species with the highest IVi 


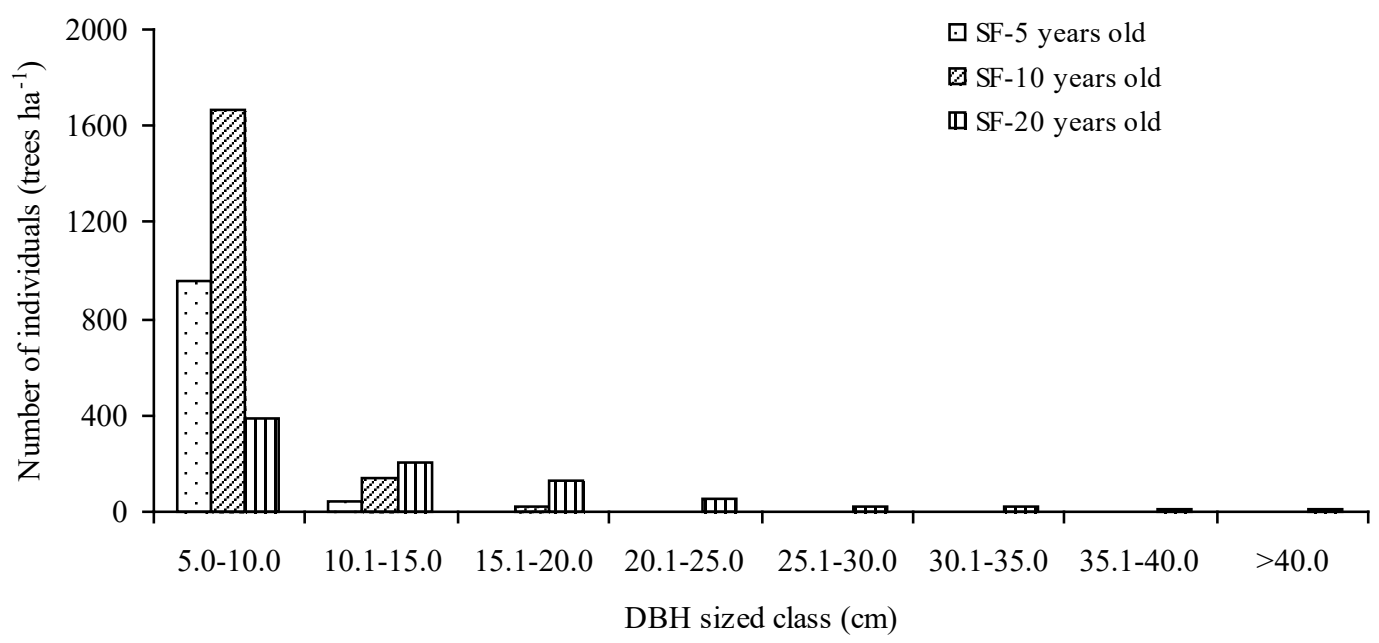

Figure 2. Distribution of tree DBH in secondary forest of different ages

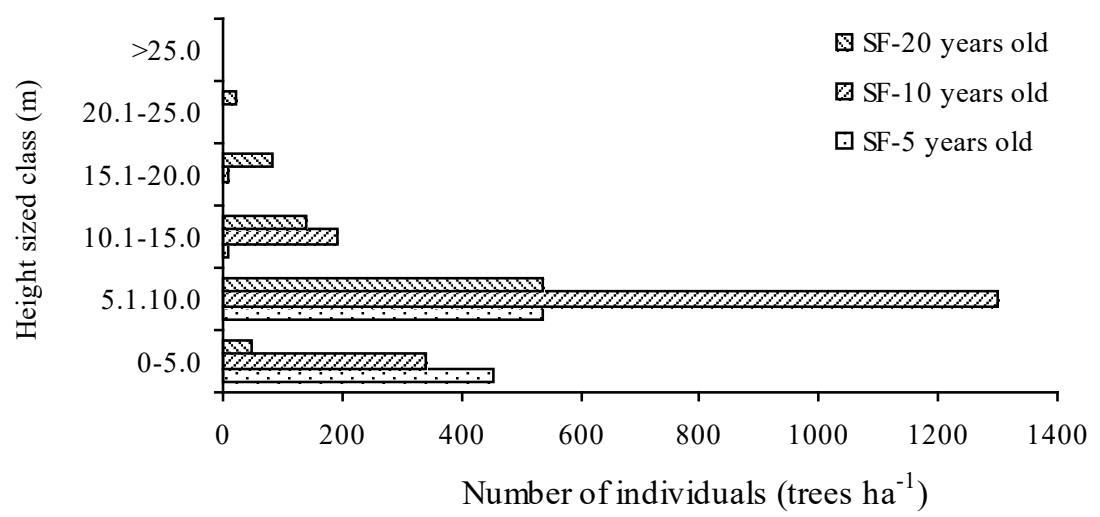

Figure 3. Distributions of tree height in secondary forests of different ages

Table 3. SØrensen similarity index (ISS) of trees with DBH of $\geq$ $5 \mathrm{~cm}$ in the study sites

\begin{tabular}{lccc}
\hline Type & $\begin{array}{c}\text { SF-5 } \\
\text { years old }\end{array}$ & $\begin{array}{c}\text { SF-10 } \\
\text { years old }\end{array}$ & $\begin{array}{c}\text { SF-20 } \\
\text { years old }\end{array}$ \\
\hline SF-5 years old & - & & \\
SF-10 years old & 41.70 & - & \\
SF-20 years old & 52.17 & 44.12 & - \\
\hline
\end{tabular}

Note: $\mathrm{SF}=$ secondary forest. Sørensen similarity index was computed for the entire study plots (1 ha)

\section{Species diversity}

The species diversity ( $H^{\prime}$ values) was categorized as 'intermediate' at all sites based on Odum (2005) classification of species diversity as presented in Table 4. There were significant differences in $H^{\prime}$ values between the 5 and the 10 year old of secondary forests, but there was no significant differences of those compared to the 20 year old of secondary forest. The ecological dominance $\left(D_{s}\right.$ value) of trees species in our studied secondary forests was categorized as 'low dominance'. There were a few species to almost no species dominant in every community. In all study sites, $D_{s}$ values showed no significant difference among them. This is typical for most tropical lowland forests. All of the trees species in the secondary forests had high value of $J^{\prime}$. Every species was distributed evenly in community. The $J$ ' values also showed no significant differences in three study sites. There were significant differences among $R$ values in all study sites. The high $J^{\prime}$ and $R$ values were due to high number of trees per hectare and number of species recorded in the study sites. The results showed that as the diversity $\left(H^{\prime}\right)$, evenness $\left(J^{\prime}\right)$, and richness $(R)$ increased, the dominance $\left(D_{s}\right)$ decreased. Sapkota et al. (2010) proved that tree diversity declines while dominance increases linearly along a disturbance gradient. The change in tree density is also related to relative basal area of the dominant tree species.

The values of Shannon-Wiener diversity index $\left(H^{\prime}\right)$ of trees $(\mathrm{DBH}$ of $\geq 5 \mathrm{~cm}$ ) varied from 2.09 to 2.70 , the Simpson dominance values $\left(D_{s}\right) 0.12-0.17$, Pielou evenness 
index $\left(J^{\prime}\right)$ 0.86-0.88, and the Margalef richness values $(R)$ 3.02 to 5.57 in all study sites. The values of $H^{\prime}$ and $R$ increased from the 5 year old to the 10 year old of secondary forests, then decreased in the 20 year old of secondary forest. The results showed that diversity indices were not related to stand age. This finding may be influenced by number of families, genera, species, and individuals in each study site. The highest number of families, genera, species, and individuals were recorded in the 10 year old of secondary forest (Table 2). Similarly, the number of species increased from tree to sapling and seedling strata in fallow stand since recruitment into the sapling of tree strata always requires the seedlings to go through the seedling stage (Van Do et al. 2011).

The tree species diversity in the 10 year old secondary forest was the highest among all study sites. In fact, this site had an intermediate disturbance compared with the others. Diversity will be greatest at an intermediate intensity, because it contains a great variety of species of both pioneer and climax species. The early stages of secondary successional process were responsible for the change and development of community structure, composition, and diversity in secondary forests of different ages. The highest diversity in 10 year old secondary forest may reflect a successional change in the intermediate age of secondary forest, mainly through reorganization in structure, composition, and diversity. The 10 year old secondary forest was the intermediate stage among all study sites. In this site, community structure, floristic composition, and species diversity looked quite different from those of the others. This may indicates that the change and dynamic of succession process began after 10 years fallow period. In Marin-Spiotta's et al. (2007) study, the successional change was shown in 30 year old sites among all studied sites. In their study, the younger secondary forests were 10 and 20 year old secondary forests, while the older secondary forests were 60 and 80 year old secondary forests. In addition, due to the poor soil fertility status in the area, 50 years of fallow period would be insufficient for the land to recover its vegetation condition, equivalent to that of natural forests (Wasli et al. 2011). The tree growth of secondary forest reflects the development during secondary succession process as well as their community structure, composition, and diversity (Karyati et al. 2017). Tanaka et al. (2007) stated that with increasing length of fallow periods, tree species replace the pioneering small plants, such as grasses, ferns, and shrubs, through vegetation succession. Some species appear during a specific period of stand development, and then disappear in older stands (Van Do et al. 2010). Wasli et al. (2009) reported no substantial differences of the species composition and the sizes of tree species between suitable and unsuitable sites of fallow lands under intensive shifting cultivation systems in the Engkari river area in Sarawak, Malaysia.

The rate of changes of plant succession attributes increased gradually at early secondary succession up to 10 years since abandonment and decreased slowly until 20 years of fallow period. This dynamic successional process was probably due to relatively high rate of recruitment and growth of seedlings and saplings at early fallow ages. At the older stages, the trees with $\mathrm{DBH}$ of $\geq 5 \mathrm{~cm}$ played an important role in the dynamics of secondary forests. The community structure, composition, and diversity varied among all studied sites. These differences were probably due to various factors, such as fallow age, community development, disturbance intensity, seed bank, and seed rain from surrounding environment, edaphic and climatic factors in each study site. In addition to being affected by the degree and frequency of disturbance during the cultivation period, early successional secondary process after shifting cultivation may also be affected by other factors, such as fire intensity and the number of cultivations, seed sources in soils or from the surrounding forests, soil fertility, and light condition (Kendawang et al. 2007), tree composition of surrounding old-growth forest and climate conditions (Van Do et al. 2010).

The study revealed that the existence of 5,10 , and 20 year old secondary forests related to their importance in community structure, floristic composition, and species diversity. The ten most common species of secondary forests were dominated by fast growing species. Their basal area and volume composed more than $60 \%$ of the total basal area and volume as well as their importance value index. The tree species of study sites were categorized as 'intermediate diversity' $\left(H^{\prime}\right)$, 'low dominance' $(D s)$, and 'high evenness' $\left(J^{\prime}\right)$. The highest species richness $(R)$ was recorded in the 10 year old secondary forest. The findings of this study were important to provide ecological data of secondary forests of different ages after abandonment. Studies on future management of secondary forests and the related issues like global climate change, biodiversity, carbon marketing and sustainability of ecosystem service of secondary forests are needed.

Table 4. Diversity indices of trees with DBH of $\geq 5 \mathrm{~cm}$ in the study sites

\begin{tabular}{llll}
\hline Diversity indices & SF-5 years old $(\mathbf{n}=\mathbf{2 5})$ & SF-10 years old $(\mathbf{n}=\mathbf{2 5})$ & SF-20 years old $(\mathbf{n}=\mathbf{2 5})$ \\
\hline Shannon-Wiener diversity index $\left(H^{\prime}\right)$ & $2.09( \pm 0.07)^{\mathrm{a}}$ & $2.70( \pm 0.14)^{\mathrm{b}}$ & $2.39( \pm 0.07)^{\mathrm{ab}}$ \\
Simpson dominance index $\left(D_{s}\right)$ & $0.17( \pm 0.01)^{\mathrm{a}}$ & $0.12( \pm 0.02)^{\mathrm{a}}$ & $0.14( \pm 0.01)^{\mathrm{a}}$ \\
Pielou evenness index $\left(J^{\prime}\right)$ & $0.86( \pm 0.01)^{\mathrm{a}}$ & $0.86( \pm 0.02)^{\mathrm{a}}$ & $0.88( \pm 0.02)^{\mathrm{a}}$ \\
Margalef species richness $(R)$ & $3.02( \pm 0.20)^{\mathrm{a}}$ & $5.57( \pm 0.52)^{\mathrm{c}}$ & $4.22\left(\underline{ \pm 0.20)^{\mathrm{b}}}\right.$ \\
\hline
\end{tabular}

Note: $\mathrm{SF}=$ secondary forest. Calculation was done according to the $20 \mathrm{~m} \times 20 \mathrm{~m}$ subplots. Values are average and standard error in parentheses. Different letters in each line indicate a significant difference at $5 \%$ level by Tukey's test among secondary forests of different ages 


\section{ACKNOWLEDGEMENTS}

We acknowledge Malaysian Palm Oil Board (MPOB) for supporting the funding of this research project. We thank Hidir Marzuki, Sekudan Tedong, Salim Arip, and Muhd Najib Fardos for their field assistance during this survey.

\section{REFERENCES}

Álvarez-Yépiz JC, Martínez-Yrízar A, Búrquez A, Lindquist C. 2008. Variation in vegetation structure and soil properties related to land use history of old-growth and secondary tropical dry forests in Northwestern Mexico. For Ecol Manag 256: 355-366.

Anderson JAR. 1980. A Check List of The Trees of Sarawak. Forest Department Sarawak, Malaysia.

Brearley FQ, Prajadinata S, Kidd PS, Proctor J, Suriantata. 2004 Structure and floristics of an old secondary rain forest in Centra Kalimantan, Indonesia and a comparison with adjacent primary forest. For Ecol Manag 195 (3): 385-397.

Dianpei W, Shuyi J, Feipeng C, Shaolin P. 2004. Composition and characteristics of natural secondary forests in Shenzhen, South China Forestry Studies in China 6 (2): 6-11.

Fachrul MF. 2007. Bioecology Sampling Method. Bumi Aksara, Jakarta. [Indonesian]

Feldpausch TR, Prates-Clark CC, Fernandes ECM, Riha SJ. 2007. Secondary forest growth deviation from chronosequence predictions in Central Amazonia. Global Ch Biol 13: 967-979.

Jawa R, Chai PK. 2007. A New Check List of The Trees of Sarawak. Lee Miing Press Sdn. Bhd, Malaysia.

Jomo KS, Chang YT, Khoo KJ. 2004. Deforesting Malaysia: The Political, Social Ecology of Agricultural Expansion and Commercial Logging. Zed Books Ltd, UK.

Kartawinata K, Riswan S, Ginting AN, Puspitojati T. 2001. An overview of post-extraction secondary forests in Indonesia. J Trop For Sci 13 (4): 621-638.

Karyati, Ipor IB, Jusoh I, Wasli ME, Seman IA. 2013. Composition and diversity of plant seedlings and saplings at early secondary succession of fallow lands in Sabal, Sarawak. Acta Biologica Malaysiana 2 (3) 85-94.

Karyati K, Ipor IB, Jusoh I, Wasli ME. 2014. Soil properties under various stages of secondary forests at Sarawak, East Malaysia. J Trop For Environ 4 (1): 28-39.
Karyati K, Ipor IB, Jusoh I, Wasli ME. 2017. The diameter increment of selected tree species in a secondary tropical forest in Sarawak, Malaysia. Biodiversitas 18 (1): 304-311.

Kendawang JJ, Ninomiya I, Tanaka K, Ozawa T, Hattori D, Tanaka S, Sakurai K. 2007. Effects of burning strength in shifting cultivation on the early stage of secondary succession in Sarawak, Malaysia. Tropics 16: 309-321.

Lawrence D. 2004. Erosion of tree diversity during 200 years of shifting cultivation in Bornean Rain Forest. Ecological Applications 14 (6): 1855-1869.

Marin-Spiotta E, Ostertag R, Silver WL. 2007. Long-term patterns in tropical reforestation: plant community composition and aboveground biomass accumulation. Ecol Appl 17 (3): 828-839.

Mittelman A. 2001. Secondary forests in the Lower Mekong Subregion: An overview of their extent, roles and importance. J Trop For Sci 13 (4): 671-690.

Odum PE. 2005. Fundamentals of Ecology, $5^{\text {th }}$ ed. Thomson Brooks/Cole, Belmont, CA

Primack RB, Hall P. 1992. Biodiversity and forest change in Malaysian Borneo. Bioscience 42: 829-837.

Sapkota IP, Tigabu M, Odén PC. 2010. Changes in tree species diversity and dominance across a disturbance gradient I Nepalese sal (Shorea robusta Gaertn. f.) forests. J For Res 21 (1): 25-32.

Tanaka S, Wasli ME, Seman L, Jee A, Kendawang JJ, Sakurai K, Morooka Y. 2007. Ecological study on site selection for shifting cultivation by the Iban of Sarawak, Malaysia. A case study in the Mujong River area. Tropics 16 (4): 357-371.

Van Breugel M, Martinez-Ramos M, Bongers F. 2006. Community dynamics during early secondary succession in Mexican tropical rain forests. J Trop Ecol 22: 663-674.

Van Do T, Osawa A, Thang NT. 2010. Recovery process of a mountain forest after shifting cultivation in Northwestern Vietnam. For Ecol Manag 259: 1650-1659.

Van Do T, Osawa A, Nguyen TT. 2011. Recovery of vegetation structure and species diversity after shifting cultivation in Northwestern Vietnam, with special reference to commercial valuable tree species. Intl Scholarly Res Network 2011: 1-12.

Wasli ME, Tanaka S, Kendawang JJ, Seman L, Unang B, Lat J, Abdu A, Morooka Y, Sakurai K. Vegetation conditions and soil fertility of fallow lands under intensified shifting cultivation systems in Sarawak, Malaysia. 2009. Tropics 18 (3): 115-126.

Wasli ME, Tanaka S, Kendawang JJ, Abdu A, Lat J, Morooka Y, Long SM, Sakurai K. 2011. Soils and vegetation condition of natural forests and secondary fallow forests within Batang Ai National Park Boundary, Sarawak, Malaysia. Kuroshio Sci 5 (1): 67-76. 